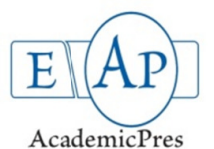

AcademicPres

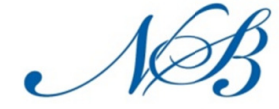

Notulae Scientia Biologicae

\title{
Control of Cherry Leaf Spot and Cherry Fruit Fly at Sour Cherry
}

\author{
Maria BOROVINOVA*, Vilina PETROVA \\ Institute of Agriculture,Kyustendil,Bulgaria; mariaborovinova@abv.bg( ${ }^{*}$ correspondingauthor)
}

\begin{abstract}
The investigations were made in the experimental sour cherry orchard from the Institute of Agriculture, Kyustendil, Bulgaria, during the period 2010-2014, in order to compare conventional and integrated sour cherry protection against cherry leaf spot and cherry fruit fly. Two variants were investigated, with two different treatment approaches for the control of cherry leaf spot and cherry fruit fly. Variant $1-$ cherry leaf spot was controlled by protective treatments with dodin and tebuconazole + trifloxystrobin and cherry fruit fly was controlled by treatments with deltametrin and thiacloprid, independently of density. Variant 2 - cherry leaf spot was controlled by post-infection (curative) treatments with tebuconazole + trifloxystrobin and cherry fruit fly was controlled by treatments based on biological threshold: 10-11 cherry fruit fly females caught in traps up to the moment for chemical treatment. It was established that Blumeriella japii can be successfully controlled by post-infection treatments and by this the number of insecticide treatments was reduced. The treatments against cherry fruit fly can be avoided or reduced when the attack control is based on the biological threshold established in the studied area.
\end{abstract}

Keywords: Blumeriella japii, control, fungal disease, pest, Rhagoletis cerasi, treatments

\section{Introduction}

The soil, climatic and topographical conditions in many region of Bulgaria are favorable for sour and sweet cherry cultivation, with proper conditions for the production of high quality fruits. Even so, it is impossible to have high quality and quantity production without plant protection practices. There are numerous fungi and pests that attack sour cherry, but cherry leaf spot caused by Blumeriella jaapii, blossom and twig blight caused by Monilinia laxa, fruit rot caused by Monilinia fructigena and Monilinia laxa are the most important fungal diseases (Borovinova, 1998, 2006; Edson et al., 1998; Feldmane, 2011; Gelvonauskienè et al., 2004; Holb, 2003, 2004; Schuster, 2004).

For the control of cherry leaf spot it is recommended to apply 4-7 treatments during the growing season, in years with favourable weather conditions (Bielenin et al., 1991; Borovinova, 2006; Holb et al., 2010). The number of fungicide treatments can be reduced by post-infection (curative) treatments, after the registration of infection (Borovinova, 1998; Borovinova and Sredkov, 2006; Eisensmith and Jones, 1981a, 1981b).

Cherry fruit fly (Rhagoletis cerasi L.) is an important pest of sour cherry that might cause economically damages in orchards (Borovinova and Sredkov, 2006; Daniel, 2014; Daniel and Grunder, 2012; Özdem and Kilinçer, 2009; Stamenković et al., 2012). One or two treatments are necessary in order to control cherry fruit fly (Daniel and Grunder, 2012; Kovanci and Kovanci, 2006; Stamenković et al., 2012; Vasev, 1983). Control of $R$ cerasi based on economic threshold application is an effective method for reducing the number of insecticide treatments (Borovinova and Sredkov, 2006).

Sour cherry fruit need a short time to ripen and for a good quality is very important to protect cherry fruit from pesticide residues. Application of post-infection (curative) treatments for cherry leaf spot and economic threshold for the control of $R$. cerasi are effective methods for reducing the number of insecticide treatments (Borovinova and Sredkov, 2006). On the other hand, the use of yellow sticky traps, crop netting, foliar applications of Naturalis-L (B. bassiana) are most suitable for the organic cherry production (Daniel and Grunder, 2012; Daniel, 2014).

The aim of this investigation was to compare conventional and integrated sour cherry protection against cherry leaf spot and cherry fruit fly.

\section{Materials and methods}

The investigations were made at the experimental sour cherry orchard of the Institute of Agriculture - Kyustendil, Bulgaria, during the period 2010-2014. Cultivar 'Erdi Bötermo' was crafted on rootstocks Mahaleb 'IK M9' and planted in 2006. Two variants were investigated, with different treatments schemes. Variant 1 (V1) - cherry leaf spot was controlled by protective treatments with dodin and tebuconazole + trifloxystrobin, while cherry fruit fly was controlled by treatments with deltametrin and thiacloprid, independently of density. Variant 2(V2) - cherry leaf spot was controlled by post-infection (curative) treatments according to the method of Eisensmith and Jones (1981a, 1981b) with tebuconazole + trifloxystrobin and cherry fruit fly was controlled by treatments based on biological threshold: 10-11 females of cherry fruit fly caught in traps up to the moment for chemical treatment (Sredkov, 2000) with pyrethrum. Yellow sticky "Rebel" traps were used for monitoring of cherry fruit fly. 
Table 1. Infections of B. jaapii (cherry leaf spot) and treatments against it during 2010-2014

\begin{tabular}{lcccccc}
\hline \multirow{2}{*}{ Year } & \multicolumn{4}{c}{ Infections } & \multicolumn{2}{c}{ No. of treatments } \\
\cline { 2 - 6 } & \multirow{2}{*}{ Total } & \multicolumn{2}{c}{ Intensity of infection } & V1 & \multirow{2}{*}{ V2 } \\
\cline { 2 - 7 } & Light & Moderate & Heavy & & \\
\hline 2010 & 19 & 5 & 5 & 9 & 3 & 4 \\
2011 & 16 & 7 & 5 & 4 & 3 & 3 \\
2012 & 20 & 7 & 10 & 3 & 4 & 4 \\
2013 & 19 & 8 & 7 & 4 & 3 & 2 \\
2014 & 27 & 8 & 3 & 16 & 3 & 3 \\
\hline V1- conventional (with protective treatments) \\
V2- integrated (with post-infection treatments)
\end{tabular}

Table 2. Rate of B. jaapii (cherry leaf spot) attack

\begin{tabular}{r|ccccc}
\hline \multirow{2}{*}{ Variant } & \multicolumn{5}{c}{ Rate of attack (\%) } \\
\cline { 2 - 6 } & 2010 & 2011 & 2012 & 2013 & 2014 \\
\hline V1 & $30.35 \mathrm{c}$ & $9.84 \mathrm{c}$ & $6.08 \mathrm{c}$ & ${ }^{*}$ & $9.76 \mathrm{c}$ \\
V2 & $7.17+++$ & $9.68 \mathrm{~ns}$ & $5.76 \mathrm{~ns}$ & ${ }^{*}$ & $11.76+$ \\
Sd & 1.514 & 0.574 & 1.183 & & 0.490 \\
F & 234.2 & 7.766 & 7.322 & 16.667 \\
LSD & 4.209 & 1.596 & 3.287 & 1.361 \\
\hline Statistical significance: $n s-$ not statistically significant, $+-\mathrm{P}<0.05 ;+++-\mathrm{P}<0.001 ;$
\end{tabular}

* - Only separate spots

For both variants, bacterial canker, brown rot and shot hole were controlled by protective treatments with copper fungicides during late autumn and early spring and 2 treatments with cyprodinil and tebuconazole during bloom period, each year of the study.

Five trees of each variant were estimated for cherry leaf spot, taking an average sample of 250 leaves from the four cardinal sides of each tree, at the end of August. The percentage of infected leaf area was estimated according to the scale of Townsend and Heuberger (Kremer and Unterstenhofer, 1967). The data for the rate (incidence) of attack of leaves by cherry leaf spot were statistically processed by analysis of variance (Maneva, 2007).

Samples of 300 fruits from the four cardinal sides of five trees of each variant during harvest were estimated for cherry fruit fly damage. Data were expressed as means, based on values noted during each year of experiment.

\section{Results and discussions}

Climatic conditions, especially the duration of wetting periods of sour cherry leaves and air temperature, were favourable for development of cherry leaf spot during all years of investigation. There were registered 3 wetting periods with heavy infection in 2012 (minimum) and 16 such periods during 2014 (maximum) (Table 1). Dependent on the wetting periods, associated with heavy infection, there were made during the study interval minimum 2 and maximum 4 post-infection treatments, per year (Table 1).
All treatments in 2012, 2013 and 2014 were applied prior to harvest, while in 2010 and 2011 two were before and one was postharvest. The post-infection treatments were efficient. The disease incidence (rate of attack of the leaves) was from very low, as it ranged between 5.76 in 2012 and to $11.76 \%$ in 2014 (Table 2). The reason of the comparatively higher rate of attack in 2012 might be due to daily rainfalls, which interfered with the application of post-infection treatments on time.

Cherry trees selected for Variant 1 were protected from $B$. jaapii by 3 or 4 fungicide treatments. Applications started at the stage of petal fall, followed at 10-14 day intervals to harvest and one or two were postharvest treatments. Simultaneously, the preventive treatments were effective. The rate of attack of the leaves was low, with one exception in 2010 (Table 2).

The present results demonstrated that Blumeriella japii can be controlled successfully by preventive and post-infection (curative) treatments. The differences between disease incidence (rate of attack on leaves) at Variant 1 and Variant 2 were not significant during the period of investigation with the exception of year 2010 when the rate of attack on leaves of Variant 1 was comparatively higher than for Variant 2, 30.35 and 7.17 respectively (Table 2 ).

Preventive treatments schedule gave effective control of cherry leaf spot and was in agreement with the results of previous studies conducted by Velitschkova (1983), who established that cherry leaf spot can be controlled successfully with 4 or 5 preventive treatments. Only in 2013 one treatment was reduced at Variant 2. Nevertheless of the decrease treatment, the cherry leaf spot infection was unimportant and only separate spots were found. That confirmed the results published by Borovinova (1994), established at sour cherry cultivar 'Schatten Morelle' in Kyustendil, when application of post-infection treatments was reduced to two treatments and still provided a good protection. The data of Eisensmith and Jones (1981a, b) about the control of cherry leaf spot of sour cherry in USA, Michigan were similar.

During the period of investigation the density of cherry fruit fly increased every year. The average number of caught flies at the two variants was minimum 5 flies per trap $(V 1,2010)$ and maximum 314 in 2013 also for V1 (Table 3). The number of females surpassed vastly the number of male flies. Independently of the density of females of cherry fruit fly at Variant 1, there were applied 1 treatment during 2011, 2014 and 2 treatments during 2012 and 2013. The rate of wormy fruits/damaged was $1.33 \%$ in 2013, and as low as 0 in 2010 and 2014 respectively (Table 3).

The density of cherry fruit fly females caught in traps during 2010, 2011, 2013 were less than the biological threshold up to the scheduled moment for chemical treatment and therefore cherry trees in Variant 2 (integrated treatments) were not treated. During harvesting, no wormy fruits were found in 2010 and 2011, while the rate of wormy fruits was $2 \%$ in 2013. Only during 2014 the density of females of cherry fruit fly surpass biological threshold and therefore one treatment was applied.

Table 3. R. cerasi attack study during 2010-2014

\begin{tabular}{|c|c|c|c|c|c|c|c|c|}
\hline \multirow[t]{2}{*}{ Year } & \multicolumn{2}{|c|}{$\begin{array}{l}\text { Beginning of flight } \\
\text { (day.month) }\end{array}$} & \multicolumn{2}{|c|}{$\begin{array}{c}\text { Density, number flies caught in } \\
\text { one trap }\end{array}$} & \multicolumn{2}{|c|}{ No. of treatments } & \multicolumn{2}{|c|}{$\%$ wormy fruits } \\
\hline & V1 & $\mathrm{V} 2$ & $\mathrm{~V} 1$ & V2 & V1 & $\mathrm{V} 2$ & V1 & $\mathrm{V} 2$ \\
\hline 2010 & $09 . \mathrm{VI}$ & $25 . \mathrm{V}$ & 5 & 13 & 0 & 0 & 0 & 0 \\
\hline 2011 & 06.VI & $30 . \mathrm{V}$ & 17 & 25 & 1 & 0 & 0.67 & 0 \\
\hline 2012 & $14 . V$ & $14 . \mathrm{V}$ & 114 & 117 & 2 & 1 & 0.33 & 0.33 \\
\hline 2013 & $15 . \mathrm{V}$ & $15 . \mathrm{V}$ & 314 & 101 & 2 & 0 & 1.33 & 2.0 \\
\hline 2014 & 12.V & $10 . \mathrm{V}$ & 240 & 131 & 1 & 1 & 0 & 0.67 \\
\hline
\end{tabular}


252

Cherry fruits were protected and the percent of wormy fruits was $0.67 \%$ (Table 3).

\section{Conclusions}

The pesticide applications at sour cherry can be reduced by post-infection (curative) treatments against cherry leaf spot and when control of cherry fruit fly is based on the biological threshold (10-11 females of cherry fruit fly caught in traps up to the moment for chemical treatment).

\section{References}

Bielenin A, Bachnacki R, Cimanowski J, Karczewski J, Olszak M, Rechinio H (1991). Effectiveness of several new fungicides in the control of cherry leaf spot. Fruit Science Reports 18(3):133-137.

Borovinova M (1994). Efect of postinfection treatments to control of cherry leaf spot (Coccumyces hiemalis Higgins). Third national scientific and practical conference of experts in fruit growing with guests from abroad, 65 Years Institute of Fruit-Growing, Kyustendil, 25-27 October, 1994.

Borovinova M, Sredkov I (2006). Comparison of integrated and conventional plant protection of cherry orchards. Not Bot Horti Agrobo 34(1):93-99.

Çetin G, Hantaş C, Soyergin S, Burak M (2008). Studies on integrated pest management (IPM) in sweet cherry orchards in the Marmara region of Turkey. Acta Hort 795:925-932.

Daniel C, Grunder J (2012). Integrated management of European cherry fruit fly Rhagoletis cerasi (L.): Situation in Switzerland and Europe. Insects 3:956-988.

Daniel C (2014). Experiences of integrated management of European cherry fruit fly (Rhagoletis cerasi) and how to utilize this knowledge for Sea Buckthorn Fly (Rhagoletis batava). Proceedings of the 3rd European Workshop on Sea Buckthorn, EuroWorkS 2014, Naantali, Finland, 1416 October 2014.

Edson CE, Laubach JE, Nugent JE, Thornton GE (1998). Integrated sour cherry (Prunus cerasus) production in Northwest lower Michigan. Acta Hort 468:505-514.

Eisensmith SP, Jones AL (1981a). Infection model for timing fungicide applications to control cherry leaf spot. Plant Disease 65:955-958.

Eisensmith SP, Jones AL (1981b). A model for detecting infection periods of Coccomyces hiemalis on sour cherry. Phytopathology 71:728-732.

Feldmane D (2011). Response of young sour cherry trees to woodchip mulch and drip irrigation. Proceedings of the 8th International scientific and practical conference "Environment. Technology. Resources" 20:252-260.

Gelvonauskienè D, Stanys V, Stanienè G (2004). Resistance stability to leaf diseases of sour cherry varieties in Lithuania. Journal of Fruit and Ornamental Plant Research 12:295-301.
Holb IJ (2003). The brown rot fungi of fruit crops (Monilinia spp.) I. Important features of their biology. International Journal of Horticultural Science 9(3-4):23-36.

Holb IJ (2004). The brown rot fungi of fruit crops (Monilinia spp.) II. Important features of their epidemiology (Review paper). International Journal of Horticultural Science 10(1):17-33.

Holb IJ, Lakatos P, Abonyi F (2010). Some aspects of disease management of cherry leaf spot (Blumeriella jaapii) with special reference to pesticide use. International Journal of Horticultural Science 16(1):45-49.

Kovanci OB, Kovanci B (2006). Effect of altitude on seasonal flight activity of Rhagoletis cerasi flies (Diptera: Tephritidae). Bulletin of Entomological Research 96:345351.

Kremer F, Unterstenhofer G (1967). De l'emploi de la metode de Townsend et Heuberger dans l'interpretation de results d'essais phytosanitares. Pflanzenschutz Nachrichten, Bayer 4:625-628.

Maneva S (2007). Mathematical modelling in plant protection. PhD Dissertation, Institute of Plant Protection, Kostinbrod (in Bulgarian).

Özdem A, Kilinçer N (2009). The effectiveness of the trap types and lures used for mass trapping to control cherry fruit fly [Rhagoletis cerasi (L., 1758)] (Diptera: Tephritidae). M Entomol Zool 4:371-377.

Schuster M (2004). Investigation on resistance to leaf spot disease (Blumeriella jaapi) in cherries. Journal of Fruit and Ornamental Plant Research 12:275-279.

Sredkov I (2000). Biological and ecological bases for control of cherry fruit fly Rhagoletis cerasi L. (Diptera: Tephritidae). PhD Diss Institute of Agriculture, Kyustendil 120 (in Bulgarian).

Stamenković S, Perić P, Milošević D (2012). Rhagoletis cerasi Loew (Diptera: Tephritidae) - Biological Characteristics, Harmfulness and Control. Pestic Phytomed (Belgrade) 27(4):269-281. 